\title{
Influence of selected additives and admixtures on underwater concrete and the environment
}

\author{
Aleksandra Mariak ${ }^{1,}$,Lucyna Grabarczyk $^{1^{*}}$, Barbara Wojtasik ${ }^{2,3}$, and Małgorzata \\ Zbawicka $^{4}$ \\ ${ }^{1}$ Gdańsk University of Technology, Faculty of Civil and Environmental Engineering, \\ ul. Narutowicza 11/12, 80-233 Gdańsk, Poland \\ ${ }^{2}$ HydroBiolLab, Research Company and Hydrobiological Laboratory, \\ ul. Żeliwna 23a, 81-159 Gdynia, Poland \\ ${ }^{3}$ University of Gdańsk, Faculty of Biology, Department of Genetics and Biosystematics, \\ ul. Wita Stwosza 59, 80-308 Gdańsk, Poland \\ ${ }^{4}$ Institute of Oceanology PAS, Sopot, Department of Genetics and Marine Biotechnology, \\ ul. Powstańców Warszawy 55, 81-712 Sopot, Poland
}

\begin{abstract}
The intensive civilization development implies searching for new possibilities connected with extension of city agglomerations, both the areas of flat building and the industrial areas. One of the most interesting solution is to use water reservoirs, rivers and sea areas. The extension of buildings affects the building materials, especially hydrotechnical concrete. Water structures are usually the objects of huge dimensions exposed to extreme conditions. In most cases these buildings are specific and complicated. They require an individual approach to concrete mix design and should be monitored by measurement technologies supported by automated numerical examinations. Nowadays health monitoring systems are applied to large variety of engineering structures. In order to get the required quality of hydrotechnical concrete, additives and admixtures are necessary. The material properties of underwater concrete can be also improved using polymer and steel fibers of various content and length. The majority of areas are built of concrete, that is the reason to be aware of admixture influence on the environment and living organisms. The attempt to evaluate the description of different kinds of hydrotechnical concrete as potential habitat of water organisms, was indicated in the paper.
\end{abstract}

\section{Introduction}

The majority of massive hydrotechnical structures require the usage of underwater concrete technology (UWC), where major issue refers to avoiding washout of binding agent from the concrete mixture. All underwater concrete techniques focus on minimization of mixture's contact with water during its supply for placement. Works organisation and uninterrupted concrete placement is a key factor here. Usually, concrete of class above C 20/25 are used. In case of underwater concreting, the requirements on technological process are more important than the concrete strength properties. In order to ensure a high liquidity of the mixture and to avoid binding agent losses, above $375 \mathrm{~kg} / \mathrm{m}^{3}$ of cement and additives per $1 \mathrm{~m}^{3}$ of concrete it is assumed. Irrespectively of UWC method, special additives AWA 
(anti-washout admixture) and admixtures - HRWR (high-range water-reducing admixture) shall be used [1-3]. Application of new generation admixtures and additives, like AWA, HRWR is more and more popular. Economic reasons related to proper organisation of works [4] and variation-prone rheological and physical and mechanical properties of concrete make us believe that the structures operated in water are most popular here.

In most cases, pebble or crushed-stone aggregate is used in underwater concrete. Mixture placed under water should be resistant to segregation and water dilution, it must spread out readily and be self-compacting [5-6]. Mineral additives used mainly in UWC include silica fumes added in the quantity of up to $8 \%$ of cement weight and fly ashes, their content approximates to $20 \%$ of cement weight. Significant improvement to the underwater concrete technology was noted in previous years, to open an opportunity for concrete as the material of the future. Many academic centres carry out tests on mixtures of cement with the addition of fly ashes, calumite or fluidized bed slag, zeolite, metakaolin and microsilica [7]. Advantageous influence of additives on concrete properties has already been proved, therefore additives are commonly used in concrete production. In the case of underwater structures it is possible to use dispersed reinforcement in a form of steel and polymer fibres [8]. The possibility to modify mechanical properties of concrete makes the structure more resistant to abrasion, erosion and corrosion [9]. Additionally, surface protection by impregnation of precast elements immersed in water makes it possible to build structures in highly aggressive environment [10].

Sometimes, in order to avoid difficult process of casting, precast concrete elements are produced. They include foundations of wind power plant or lightweight concrete slabs as foundations of floating houses [11]. Another aspect is monitoring of concrete elements, both, during the concrete placement and exploitation of the structure. Advanced measurement techniques in combination with numerical simulations allow prediction and monitoring of the changes of thermal and strength parameters as well as condition of underwater concrete over time [12-14].

Technology of concrete placement in a structure is important, this is the key factor of quality and durability of the object. Any errors during underwater concrete casting are usually disastrous for the structure and their repair is very expensive. They are, however, not all the factors to be taken into account. Also, concrete components used and concreting technology are of significant importance for the water organisms. The aim of the paper is to determine the effect of underwater concrete components on water parameters $(\mathrm{pH}$ and electrolytic conductivity) and intensity of settlement by living organisms.

\section{Selected admixtures and additives to underwater concrete}

A characteristic admixture for underwater concrete is a superplasticizer, i.e. HRWR. At the moment, new generation admixtures are added to UWC, which are produced using the latest technology.

\subsection{Admixtures based on hybrid polymers}

Hybrid polymers-based admixture, due to the application of knowledge about synthesis of molecules, enables a high range of efficient dosing, strong reduction of batch water content, long-lasting consistency as well as homogeneity and cohesion of concrete mixture. It features very strong dispersing activity in relation to fine fractions facilitating liquid consistency of concrete mixture to be achieved. At the same time, it enables desired liquidity to be kept for a very long time. It contains $20 \%$ of sodium nitrate, fish toxicity of which is classified in Category 4 (Practically non-toxic and not an irritant, CL50 > 1000 $\mathrm{mg} / \mathrm{l} / 96 \mathrm{~h})$. The product is not classified as environmentally hazardous. 


\subsection{Admixtures based on stabilised polycarboxylates}

The produced admixture based on stabilised polycarboxylates was developed especially for concrete mixtures featuring high flowability and ability to fill up the moulds. It assures long-lasting, stable consistency, ensuring high immunity to any changes of water content at the same time. Additionally, concrete with polycarboxylate admixture features fast strength increase at early setting stages, also when CEM II and CEM III are used, or fly ash is added, which may be of high importance for placing concrete underwater. The product is not classified as environmentally hazardous.

\subsection{Admixture based on modified polycarboxylates and phosphonates}

Another admixture is an admixture based on modified polycarboxylates and phosphonates. Due to its special molecular structure it enables production of cohesive mixture of low viscosity and long-lasting consistency. It is recommended for mixtures of very high workability and low water-cement ratio. It ensures long-lasting properties of mixture without retardation of setting time. In the case of this admixture no aquatic toxicity information is available.

\subsection{Anti-washout admixtures}

Powder admixture preventing washout in water during placement enables achieving liquid consistency mixture at washout loss below 3\%. It makes the mixture resistant to washout and separation, significantly facilitating underwater integration. AWA admixture contains $10 \%$ of calcium formate (fish toxicity of Category 4 - Practically non-toxic and not irritant, CL50 $>1000 \mathrm{mg} / \mathrm{l} / 96 \mathrm{~h}$ ). Similarly to HRWR it is not classified as environmentally hazardous. In line with EN 934-2 standard [15], AWA belongs to a group of complex admixtures, while HRWR to plasticizing admixtures (superplasticizers).

\subsection{Fly ash}

Fly ash is a fine-grained fraction of ashes produced during fuel combustion. Addition of fly ash ensures better workability of concrete mixture, improves concrete durability and reduces hydration temperature, preventing the risk of shrinkage in fresh concrete [16]. Application of ashes (with some limitations) is also economically justified as it allows replacement of some portion of cement with much cheaper material [17].

While considering the impact of ash content in concrete on aquatic environment, it is important to mention ashes filtrate featuring high salt content which is easily and quickly washed out, without posing, however, any environmental hazard. Water extracts from ashes obtained in laboratory research feature increased alkalinity, increased $\mathrm{pH}$ and increased content of $\mathrm{SO}_{4}{ }^{2-}$ ions. At the same time, the waters are free of organic contaminations, biogenic substances as well as other substances adversely influencing the environment [18].

Combined application of AWA, HRWR admixtures and fly ashes (Table 1) proved to be very efficient in production and placement of concrete mixture under water. Interaction of the above components enables washout of binding agents from concrete mixture and bleeding to be reduced to minimum. This provides significantly better visibility during underwater concreting operations. At the same time, the mixture maintains pumping consistency and self-compacting properties. Finally, it allows to obtain UWC of high strength and quality [19-21]. 
Table 1. Chemical composition of fly ash.

\begin{tabular}{|c|c|c|c|c|}
\hline Component & {$[\%]$} & Component & {$[\%]$} & urpinska. \\
\hline $\mathrm{SiO}_{2}$ & 54,78 & $\mathrm{Na}_{2} \mathrm{O}$ & 1,25 & \\
\hline $\mathrm{Al}_{2} \mathrm{O}_{3}$ & 24,17 & $\mathrm{P}_{2} \mathrm{O}_{5}$ & 0,53 & \\
\hline $\mathrm{Fe}_{2} \mathrm{O}_{3}$ & 6,36 & $\mathrm{SO}_{3}$ & 0,57 & \\
\hline $\mathrm{CaO}$ & 4,28 & $\mathrm{TiO}_{2}$ & 1,35 & \\
\hline $\mathrm{MgO}$ & 3,06 & Ig-loss & 2,73 & \\
\hline $\mathrm{K}_{2} \mathrm{O}$ & 3,37 & & & $\longmapsto 100 \mu \mathrm{m}$ \\
\hline
\end{tabular}

\section{Influence of underwater concrete on aquatic organisms}

The preliminary results of the authors' research [22] were published at the 8th International Scientific Conference, Toxic Substances in the Environment Toxe 2017. The aim of the research was to state if there is any influence of hydrotechnical concrete components on survivability of organisms inhabiting concrete elements.

The research was carried out on two concrete types: regular UWC (with AWA and HRWR added) and concrete with artificial aggregate modified with additives. Zebra mussel (Dreissena polymorpha), commonly present in freshwater reservoirs of low salt content, was used as a bioindicator [23]. Underwater concrete was ascertained to have lethal influence on D. polymorpha. Parameters of electrolytic conductivity and $\mathrm{pH}$ did not exceed the values present in lakes inhabited by that types of organisms. Therefore, the possibility of presence of compounds toxic for Zebra mussel emerging as a result of reaction in aquatic environment (lake) [22-25] shall be taken into account.

Up till now the aquatic organisms growing on concrete surface were a common phenomenon, considered the situation of adverse influence on concrete rather than the impact of living organisms. Natural components used in concrete production did not hinder mussels' settlement on concrete's surface, which were often growing in very large colonies. With regard to new concrete components which have appeared on the construction market, it was decided to carry out an experiment to check the influence of selected admixtures and additives on the settlement of living organisms on the surface of modified UWC.

\section{Materials and methods}

The experiments were conducted for three different compositions of UWC (no. 1, 2, 3). The compositions of concrete mixtures were shown in Table 2 . Two types of lake water were selected, one originating from reservoir of good ecologic conditions: Wdzydze lake $(W)$ and one from ecologically degraded lake: Klasztorne Małe lake in Kartuzy $(K)$ (Fig. 1a).

a)

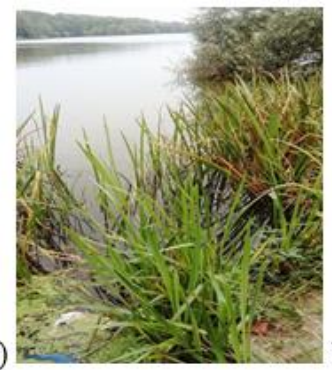

b)

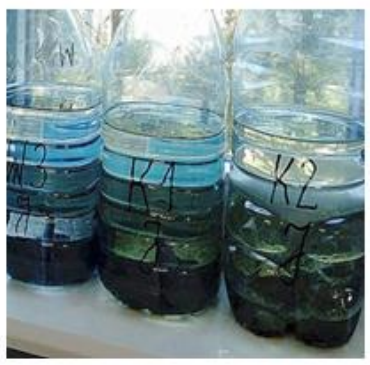

Fig. 1. a) Experimental site in natural environment, b) Method of samples seasoning. 
Table 2. The compositions of concrete mixtures.

\begin{tabular}{|l|c|c|c|}
\hline \multirow{2}{*}{ Component/ Properties } & \multicolumn{3}{|c|}{ Concrete number } \\
\cline { 2 - 4 } & $\mathbf{1}$ & $\mathbf{2}$ & $\mathbf{3}$ \\
\cline { 2 - 4 } & \multicolumn{3}{|c|}{$\left[\mathrm{kg} / \mathrm{m}^{3}\right]$} \\
\hline CEM I 52,5 N & 420 & - & - \\
\hline CEM II/A-V 42,5 R & - & 380 & - \\
\hline CEMIV/B(V) 32,5 R & - & - & 260 \\
\hline Water & 145 & 165 & 156 \\
\hline Silica sand 0/2mm & 642 & 677 & 821 \\
\hline Gravel 2/8 mm & - & 512 & 515 \\
\hline Gravel 8/16 mm & - & 512 & 573 \\
\hline Granite grit 2/8 & 495 & - & - \\
\hline Granite grit 8/16 & 697 & - & - \\
\hline $\begin{array}{l}\text { HRWR admixture based on hybrid } \\
\text { polymers }\end{array}$ & - & - & 1.6 \\
\hline $\begin{array}{l}\text { HRWR admixture based on } \\
\text { stabilised polycarboxylates }\end{array}$ & 2.50 & - & - \\
\hline $\begin{array}{l}\text { HRWR admixture based on modified } \\
\text { polycarboxylates and phosphonates }\end{array}$ & - & 3.50 & - \\
\hline AWA type admixture & - & 1,50 & - \\
\hline water / cement ratio & 0,35 & 0,43 & 0,60 \\
\hline${\left.\text { fc2 [N/mm }{ }^{2}\right]}^{\text {fc28 [N/mm }{ }^{2} \text { ] }}$ & 59,2 & 26,8 & 9,5 \\
\hline fc56 [N/mm ${ }^{2}$ ] & 87,7 & 44,9 & 26,2 \\
\hline & 92,6 & 50,2 & 33,2 \\
\hline
\end{tabular}

The two-fold nature of the experiment was assumed: tests in natural environment and simultaneously in laboratory conditions (Fig. 1b). Before the experiments started, basic physical and chemical parameters of lake water had been measured: electrolytic conductivity $(\mathrm{C})$ and $\mathrm{pH}$ (Table 3 ). Water temperature for experiment carried out in natural environment was adjusted to annual variability of temperature curve for a selected reservoir ( $W$ and $K$ ). In laboratory conditions, tests were carried out in the temperature of approximately $20^{\circ} \mathrm{C}$ (summer conditions in natural environment for coastal, littoral zone) with natural lighting and approx. $4-5^{\circ} \mathrm{C}$ without lighting (simulation of profundal zone).

Table 3. Water parameters before the experiment .

\begin{tabular}{|l|c|c|}
\hline Water parameter & W0 & K0 \\
\hline $\mathrm{C}[\mu \mathrm{S} / \mathrm{cm}]$ & 251 & 385 \\
\hline $\mathrm{pH}$ & 7,667 & 8,225 \\
\hline
\end{tabular}

In natural environment experiment (Fig. 1a) $100 \mathrm{~mm}$ cubic concrete specimens were placed at the lakes bottoms in littoral zone. In laboratory part, 12 control reservoirs were established ( 2 water types, 3 concrete types, 2 storage environments) with $50 \mathrm{~mm}$ cubic concrete samples put inside (Fig. 1b).

Control measurements were planned 1, 3 and 6 months after experiments had started. The degree of growing of small aquatic organisms (microorganisms, algae, small invertebrates) on the concrete surface was evaluated using innovative dyeing method [26], in which the achieved images allow for evaluation of intensity and time of growing in different experimental conditions. Figure 2 shows pictures of concrete specimen without dyeing (Fig. 2a) as well as during dyeing (Fig. 2b). Based on images obtained as a result of dyeing with Rose Bengal a diverse degree of concrete inhabiting by small aquatic organisms was archived (Fig. 2c, 2d). 
a)

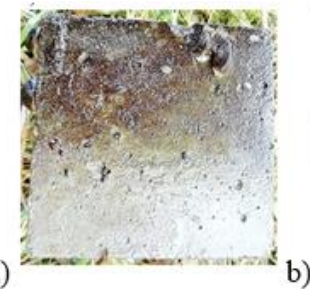

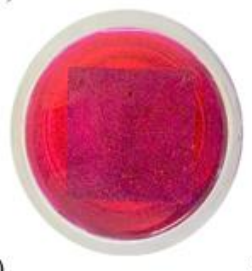

c)
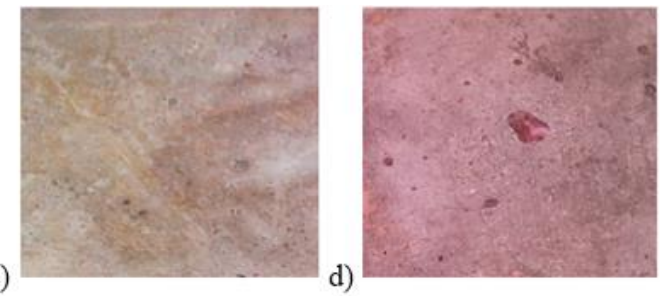

Fig. 2. a) Sample of concrete number 3 without dyeing, directly after taking it out from a lake, b) Dyeing process, c) Dyeing result - low degree of concrete inhabitation, d) Dyeing result - total coverage of concrete wall by small aquatic organisms; observations were carried out after 1 month of experiment time (photo: L. Grabarczyk).

\section{Results and discussion}

A month since the experiment had started, preliminary measurements of basic water parameters were taken and the process of dyeing of control samples was started. The results are presented in Table 4 and $5(W 0, K 0$ - initial parameters of water sampled from natural environment in $W$ and $K$ lakes).

Table 4. Change of water parameters $(\mathrm{C}$ and $\mathrm{pH})$ in laboratory reservoirs at $20^{\circ} \mathrm{C}$.

\begin{tabular}{|l|c|c|c|c|}
\hline & $\boldsymbol{W 0}$ & $\boldsymbol{W 1 - 1}$ & $\boldsymbol{W 2 - 1}$ & $\boldsymbol{W 3 - 1}$ \\
\hline $\mathrm{C}[\mu \mathrm{S} / \mathrm{cm}]$ & 251 & 516 & 542 & 548 \\
\hline $\mathrm{pH}$ & 7,667 & 8,645 & 8,721 & 8,814 \\
\hline & $\boldsymbol{K 0}$ & $\boldsymbol{K 1 - 1}$ & $\boldsymbol{K 2 - 1}$ & $\boldsymbol{K 3}-\mathbf{1}$ \\
\hline $\mathrm{C}[\mu \mathrm{S} / \mathrm{cm}]$ & 385 & 697 & 745 & 771 \\
\hline $\mathrm{pH}$ & 8,225 & 9,123 & 9,219 & 9,336 \\
\hline
\end{tabular}

Table 5. Change of water parameters $(\mathrm{C}$ and $\mathrm{pH})$ in laboratory reservoirs at $5^{\circ} \mathrm{C}$.

\begin{tabular}{|l|c|c|c|c|}
\hline & $\boldsymbol{W} 0$ & $\boldsymbol{W 1 - 1}$ & $\boldsymbol{W 2 - 1}$ & $\boldsymbol{W 3 - 1}$ \\
\hline $\mathrm{C}[\mu \mathrm{S} / \mathrm{cm}]$ & 251 & 364 & 397 & 401 \\
\hline $\mathrm{pH}$ & 7,667 & 9,045 & 9,124 & 9,218 \\
\hline & $\boldsymbol{K 0}$ & $\boldsymbol{K 1 - 1}$ & $\boldsymbol{K 2 - 1}$ & $\boldsymbol{K 3}-\mathbf{1}$ \\
\hline $\mathrm{C}[\mu \mathrm{S} / \mathrm{cm}]$ & 385 & 489 & 512 & 539 \\
\hline $\mathrm{pH}$ & 8,225 & 9,538 & 9,689 & 9,831 \\
\hline
\end{tabular}

The dyeing colour shade was evaluated on samples dried at $105^{\circ} \mathrm{C}$. At the time of publication drying still continues. Preliminary evaluation of freshly dyed samples allows to conclude that in the first 30 days of experiment, living organisms have grown on concretes in a quite large number, irrespectively of their type and environment. Detailed evaluation will allow for a more precise determination the concrete type and environment to create the most friendly conditions for microorganisms and algae settlement.

Regarding samples taken from natural environment single pieces of small invertebrates were observed, mainly on concrete no. 3 (Fig. 2a) - already such preliminary results allow for conclusion that not all underwater concretes (UWC) are lethally toxic for living organisms. The obtained images of concrete dyeing indicate diverse degree of inhabiting the concrete by small organisms at $20{ }^{\circ} \mathrm{C}$, from insignificant degree up to the total coverage of the concrete's surface (Fig. 2c, 2d). Both the values of electrolytic conductivity and $\mathrm{pH}$ increased, whereas the value of electrolytic conductivity (C) has almost doubled. The results of $\mathrm{C}$ and $\mathrm{pH}$ values for $W$ and $K$ series samples are compared in Fig. 3 at $20^{\circ} \mathrm{C}$ and in Fig. 4 at $5^{\circ} \mathrm{C}$. The conduced experiment proved the following:

- diverse degree of inhabiting concrete surface by aquatic organisms, 
- influence of concrete on water parameters, like electrolytic conductivity and $\mathrm{pH}$, while the increase of electrolytic conductivity is significant as compared to initial value,

- increase of electrolytic conductivity depends on the concrete sample used, the highest is for $\mathrm{K} 3$ sample incubated in ecologically degraded environment,

- differences in values of both, $\mathrm{pH}$ and conductivity, depend on experiment temperature,

- differences of concrete composition influence on diversification of water parameters, which may translate into various degree of environment attractiveness for living organisms,

- the largest changes of both $\mathrm{pH}$ and electrolytic conductivity were observed in ecologically degraded environment in concrete 3 .
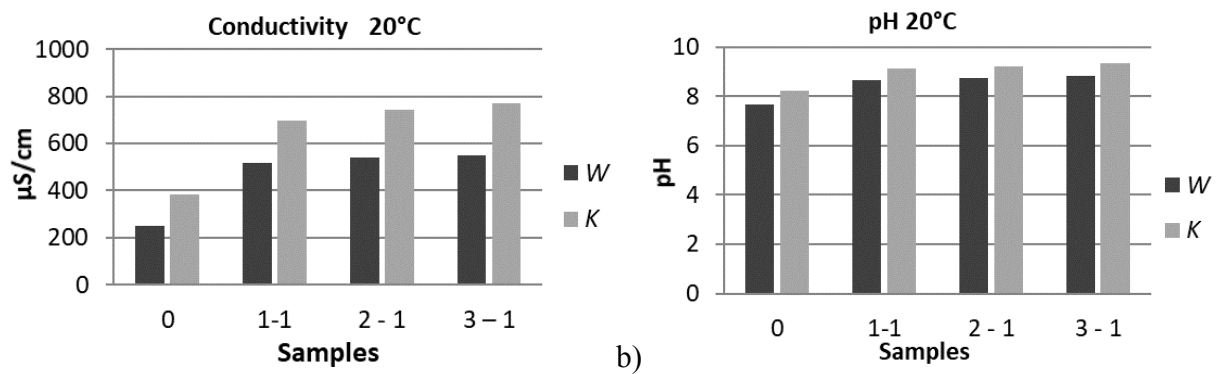

Fig. 3. Laboratory reservoirs at $20^{\circ} \mathrm{C}$ : a) changes of electrolytic conductivity, b) changes of water $\mathrm{pH}$.
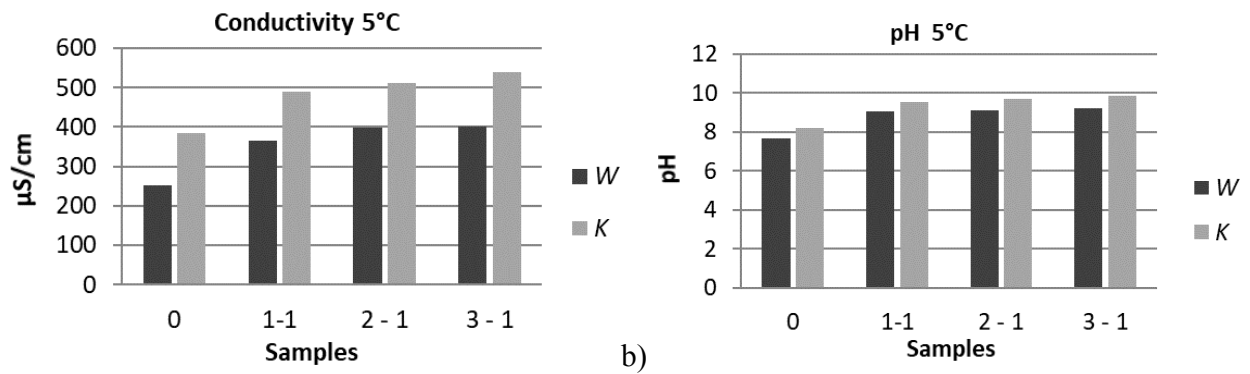

Fig. 4. Laboratory reservoirs at $5^{\circ} \mathrm{C}$ : a) changes of electrolytic conductivity, b) changes of water $\mathrm{pH}$

\section{Summary}

Based on the results of the first stage of the studies, after 30 days of exposure of different concretes in water environments, it can be concluded that the highest impact on changes in water parameters concerns concrete number 3 with an HRWR admixture based on hybrid polymers. The tests showed an approximately two-fold increase in electrolytic conductivity. $W$ reservoir the change ranges from $251 \mu \mathrm{S} / \mathrm{cm}$ to $548 \mu \mathrm{S} / \mathrm{cm}$.

In the case of assessment of the degree of growing small organisms on concrete surface was carried out by an innovative dyeing method, at the same time as the water tests. After the first month of the experiment, the surface of the concrete with an HRWR admixture based on hybrid polymers was most often settled. On the other hand, in concrete with an AWA admixture and HRWR admixture based on modified polycarboxylates and phosphonates, a weak dyeing effect indicating a negligible amount of organisms has been noticed. The next research step will be carried out after 3 and 6 months of storage of concrete in the aquatic environment. 


\section{References}

1. K. H. Khayat, M. Sonebi, ACI Materials Journal, 98, 4, 289-295, (2001)

2. K. H. Khayat, J. Assaad, ACI Materials Journal, 100, 3, 185-193, (2003)

3. V. S. Ramachandran, Concrete Admixtures Handbook: Properties, Science and Technology, (1995)

4. B. Grzyl, E. Miszewska-Urbańska, M. Apollo, E3S Web of Conferences, EDP Sciences, 17, (2017)

5. M. Sonebi, Cement and Concrete Research, 31, 11, 1553-1560, (2001)

6. M. Sonebi, K. H. Khayat, ACI Materials Journal, 98, 3, 233-239, (2001)

7. M. Hara, S. Sogo, Marine Concrete International Conference on Concrete in Marine Environment, Concrete Society, London, 440-448, (1986)

8. A. Mariak, M. Kurpińska, II Baltic Conference for Students and Young Researchers BalCon2018, (to be published)

9. M. Kurpińska, T. Ferenc, Shell Structures: Theory and Applications, 4, 549-552, (2018)

10. M. Kurpińska, Drogi i Mosty, 1-2, (2011)

11. M. Kurpińska, T. Ferenc, II International Conference of Computational Methods in Engineering Science, (2017)

12. M. Miśkiewicz, Ł. Pyrzowski, K. Wilde, O. Mitrosz, Polish Maritime Research, 24, 149-155, (2017)

13. A. Mariak, J. Chróścielewski, K. Wilde, Shell Structures: Theory and Applications, 4, 557-560, (2018)

14. A. Mariak, M. Kurpińska, K. Wilde, 64 Scientific Conference Krynica Zdrój, Poland, (2018), (to be published)

15. EN 934-2, Admixtures for concrete, mortar and grout. Concrete admixtures. Definitions, requirements, conformity, marking and labelling

16. K. H. Khayat, M. E. Gattioui, C. Nmai, Fifth International CANMET/ACI Conference, SP-173, ACI, Mich, (1997)

17. P. Freidenberg, E. Freidenberg, Przegląd budowlany, 10, 32-35, (2007)

18. B. Broś, Aura Ochrona Środowiska, 10, 13-16, (1992)

19. E. Horszczaruk, P. Brzozowski, Constr. Build. Mater., 72, 167-173, (2014)

20. E. Horszczaruk, P. Brzozowski, Procedia Engineering, 196, 97-104, (2017)

21. H. Falkner, V. Henke, Cement and Concrete Composites, 20, 5, 377-385, (1998)

22. B. Wojtasik, M. Zbawicka, L. Grabarczyk, M. Kurpińska, Toxic Substances in the Environemnt, (2017)

23. P. Elliott, D. C. Aldridge, G. C. Moggridge, Water Res. 42, 1664-1674, (2008)

24. B. R. Smith, D. R. Edds, Transactions of the Kansas Academy of Science, 117 (3 \& 4), 159-166, (2014).

25. B. W. Kilgour, G. L. Mackie, Zebra mussels: biology, impacts, and control, Lewis Publishers, Boca Raton, Florida, 167-173, (1993)

26. B. Wojtasik, A method of assessing the biological corrosion of porous structures, including concrete, in particular hydrotechnical concrete. Patent application No. P.421947 Polish Patent Office (2017) 